\title{
EVALUATION OF ORIGANUM VULGARE ESSENTIAL OIL AS ANTIMICROBIAL AGENT IN SAUSAGE
}

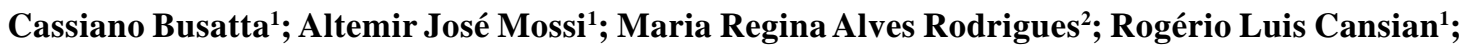 \\ José Vladimir de Oliveira ${ }^{1 *}$
}

${ }^{1}$ Departamento de Engenharia de Alimentos, Universidade Regional Integrada, Erechim, RS, Brasil; ${ }^{2}$ Departamento de Química Orgânica, Instituto de Química e Geociências, Universidade Federal de Pelotas, Pelotas, RS, Brasil

Submitted: April 01, 2007; Returned to authors for corrections: September 20, 2007; Approved: November 15, 2007.

\begin{abstract}
This work reports antimicrobial activity of oregano (Origanum vulgare) essential oil against several bacteria in sausage. The in vitro minimum inhibitory concentration (MIC) was determined for 9 selected aerobic heterotrofic bacteria. The antimicrobial activity of distinct concentrations of the essential oil on the basis of the highest MIC found was tested in a food system comprised of fresh sausage. Batch food samples were also inoculated with Escherichia coli with a fixed concentration and the time course of the product was evaluated with respect to the action of the different concentrations of essential oil. Sensory analysis were conducted, and results showed that the addition of oregano essential oil to sausage may be a promising route as bacteriostatic effect was verified for oil concentrations lower than the MIC.
\end{abstract}

Key words: Antimicrobial properties, oregano (Origanum vulgare), food system, fresh sausage

\section{INTRODUCTION}

Research in essential (volatile) oils has attracted increased attention from both academic and industrial circles due to a growing interest in green consumerism, world-wide reduction in the composition of salt in food (health reasons), and the need of alternative techniques to assure quality and safety of perishable foods $(4,15)$. Essential oils of aromatic and medicinal plants present a great potential of application as antimicrobial agents and their use as remedies has been recognized for long time (20).

In addition to antimicrobial properties, essential oils or their components have shown to exhibit antiviral, antimycotic, antitoxigenic, antiparasitic, and insecticidal properties, which are possibly related to the function of these compounds in plants (4). Excellent review papers are available on this subject in the specialized literature $(4,15)$.

Though synthetic chemical additives have been added during food manufacture to extend products shelf-life through preventing or inhibiting microbial growth, coherently with "green" image, the use of natural preservatives has become popular. As a consequence, plant essential oils having antimicrobial activity against a broad spectrum of microorganisms is of great interest.

Essential oils are aromatic oily liquids obtained from plant material (flowers, buds, leaves, seeds, fruits, roots, twigs, barks, herbs and wood) and are in fact a complex mixture of hydrocarbons, alcohols, esters, aldheydes, carboxylic compounds and, in some cases, phenylpropanoids. The most frequent hydrocarbons are terpenic compounds, but sesquiterpenes can also be found. The antibacterial properties of essential oils have been attributed to the presence of phenolic components and though other constituents are believed to have little effect, synergistic effects should not be neglected a priori $(4,15)$.

Although several studies have been conducted regarding in vitro antibacterial and antifungal properties of plant essential oils and extracts $(4,32)$, just a few studies on the activity of essential oils in food systems have been reported in the literature (15). It is well known that the antimicrobial potency of essential oils in food systems is generally reduced when compared to in vitro work, as the presence of fats, carbohydrates, proteins,

*Corresponding Author. Mailing address: Av. Sete de Setembro, 1621, Erechim RS, Brasil, 99700-000. E-mail: vladimir@uricer.edu.br 
salts and $\mathrm{pH}$ strongly influence the effectiveness of these agents (4). Accordingly, higher amounts of essential oils are required in food systems, thus seriously interfering in the final organoleptical aspects (23). In this sense, the influence of food composition on antimicrobial effectiveness of essential oils comprises a challenging and important area of study (15).

Among several essential oils that may be useful as antimicrobial agents, oregano oil (Origanum vulgare) may have a great potential for industrial applications $(2,7,9,10)$. Undoubtedly, oregano has been recognized as one of the most used vegetable all over the world, with abundant occurrence in East Europe, in the Middle Asia and South and North America $(21,33)$. Some properties like antimicrobial, antioxidant and antimutagenic activities have been attributed to the essential oil from Origanum $(3,8,18)$.

Several oregano species are characterized by the presence of two main chemotypes, thymol and carvacrol. Another intermediate type would contain high content of two monoterpene hydrocarbons, $\gamma$-terpinene or p-cymene. But, some species were found with high values of linalool and other monoterpenes and sesquiterpenes $(6,12,22,24-27)$.

The present paper is part of a broader project aiming the evaluation of some kinds of Labiatae species of plants, mainly Marjoran and Origanum, as antimicrobial agents in vitro and, mainly, in food systems. In this context, the goal of this work is to evaluate in vitro and in food antimicrobial activity of oregano essential oil obtained from hydrodistillation. Minimum inhibitory concentration (MIC) values were determined for 9 selected aerobic heterotrofic bacteria. The essential oil potency was tested in fresh sausage and sensory analyses were conducted in the resulting products for different oil concentrations.

\section{MATERIALS AND METHODS}

\section{Materials}

Samples of oregano (dried leaves from Chile) were purchased from TecPharma Importação de Produtos Químicos e Farmacêuticos LTDA. These samples were crushed manually and stored under nitrogen atmosphere until the extraction. The analytical standards $\alpha$-pinene, $\beta$-pinene, $p$-cymene, camphene, $\alpha$-terpinene, limonene, $\gamma$-terpinene, linalool, terpineol- $4, \alpha$ terpineol, carvacrol, thymol and biphenyl are purchased from Aldrich, Palo Alto, CA, USA. A stock solution of each standard was prepared at $1000 \mathrm{mg} / \mathrm{L}$ in dichloromethane (Merck, PA grade, bi-distilled) and stored under refrigeration. Additional details regarding chemical characterization of oregano oil can be found in the work of Rodrigues et al. (26).

\section{Methods}

The extractions were performed in a Clevenger apparatus for $95 \mathrm{~min}$ and the yield of essential was recorded at each $5 \mathrm{~min}$. Density of essential oil measured by the gravimetric method afforded $0.92 \mathrm{~g} / \mathrm{mL}$ at room temperature $\left( \pm 20^{\circ} \mathrm{C}\right)$. After hydrodistillation runs, water was removed by decantation and the essential oil obtained was stored at $4^{\circ} \mathrm{C}$ and protected against light to avoid alteration in its composition.

\section{Analytical methods}

The essential oil was analyzed with a gas-chromatograph interfaced with a mass selective detector-GC/MSD (Shimadzu, Model QP 5050A), using a capillary column DB-5 (30 m x 0.25 $\mathrm{mm} \times 0.25 \mu \mathrm{m}$ ); flow rate of $1 \mathrm{~mL} / \mathrm{min}$ (Helium as carrier gas); in electronic impact mode of $70 \mathrm{eV}$ and in split mode (split ratio 1:30). The following oven temperature gradient programming was adopted: $50^{\circ} \mathrm{C}$ heating to $100^{\circ} \mathrm{C}$ at $2^{\circ} \mathrm{C} / \mathrm{min}$, to $145^{\circ} \mathrm{C}$ at $3^{\circ} \mathrm{C} / \mathrm{min}$ and to $280^{\circ} \mathrm{C}$ at $5^{\circ} \mathrm{C} / \mathrm{min}$ ( $25 \mathrm{~min}$ hold). The interface temperature was kept at $280^{\circ} \mathrm{C}$. The identification of major compounds was accomplished by comparing their retention times with those of authentic standards, and by comparison their mass spectra with those from the Wiley library. Compositions are then expressed as percent of normalized peak areas.

\section{In vitro tests of antimicrobial activity}

According to Katzung (19), the disk diffusion methods are satisfactory to determine the sensibility of several microorganisms against many pharmaceutical substances, and are sufficient when the resistance mechanism is due to the degradation of the antimicrobial agent by the microorganism. In this work, the sensitivity degree or resistance of the 18 microorganisms shown in Table 1 was preliminarily tested by measuring the size of the zones of antimicrobial effect (size of halo formed).

For this purpose, Watmann number 3 paper disks with $7 \mathrm{~mm}$ diameter soaked with $5 \mu \mathrm{L}$ of oregano essential oil were laid on top of Agar Muller-Hinton (Merck) culture medium plate previously inoculated $\left(100 \mu \mathrm{L}-10^{8} \mathrm{CFU} / \mathrm{mL}\right)$ with the different microorganisms tested in this work. Samples were examined in triplicate, separately, against each bacterium together with a negative control disk and another for positive control (Chloramphenicol $30 \mu \mathrm{g}$ ). Afterwards, 9 bacteria were selected based on the halo size and on the relevance to the food product examined. MIC values were measured by the optical density method.

The bacteria were then inoculated in micro-tubes $(10 \mu \mathrm{L}$ $10^{8} \mathrm{CFU} / \mathrm{mL}$ ) in $150 \mu \mathrm{L}$ of Luria Bentani (LB) liquid medium (triptone $10 \mathrm{~g} / \mathrm{L}$, yeast extract $5 \mathrm{~g} / \mathrm{L}, \mathrm{NaCl} 5 \mathrm{~g} / \mathrm{L}$ ), containing the essential oil at different concentrations, by 24 hours in oven maintained at $35^{\circ} \mathrm{C}$. The optical density of the samples was evaluated at the beginning and 24 hours (Bio-Tec Instruments Inc., model EL800), with wavelength of $490 \mathrm{~nm}$. The following concentrations of the essential oil was tested for the nine bacteria: $0 ; 0.046 ; 0.069 ; 0.092 ; 0.23 ; 0.46 ; 0.598 ; 0.690 ; 0.782$; $0.92 ; 2.3$ and $4.6 \mathrm{mg} / \mathrm{mL}$. Bacterial growth was determined by 
computing the difference between recorded optical density measurements in triplicate at zero and after 24 hours.

\section{Antimicrobial activity in a food system}

Towards evaluating the antimicrobial activity of oregano essential oil in a food system, a sufficient amount of fresh sausage was prepared following the actual Brazilian legislation (ANVISA), stored under refrigeration at $4^{\circ} \mathrm{C} \pm 1.0^{\circ} \mathrm{C}$, and tested using three distinct oil concentrations with respect to the highest MIC found for all tested bacteria: equal to, 2 times and 5 times of this MIC value. Of course, in addition to these sample tests, a reference blank (control) test without the oil was also employed.

In order to prepare the food system, the essential oil and sausage were mixed with the help of dehydrate sodium chloride $(\mathrm{NaCl})$. The same number of samples was inoculated with Escherichia coli, previously grown in nutrient broth (Merck) for 24 hours at $37^{\circ} \mathrm{C}$ and diluted to the concentration of $1 \times 10^{3}$ MPN/g. The following oil concentrations in relation to the highest MIC found were used: half, equal and $21 \frac{1}{2}$ times.

To evaluate the antimicrobial potency in the food system, tests were carried out using heterotrofic aerobic bacteria following the method of Silva et al. (29). These analyses were performed for a period of $0,10,20,25,30$ and 35 days. For the food samples containing Escherichia coli analyses were carried out adopting the most probable number (MPN) technique, as mentioned by Silva et al. (29). In this case, the chosen period of time was $0,10,15,20$ and 30 days.

\section{Sensory analysis}

To evaluate the sensory characteristics (global test) of the food system, it was adopted the control difference method as described by Faria and Yotsuyanagi (11), which consists in a 9point structured scale: 1- extremely worse than the standard; 5equal to the standard, and 9- extremely better than the standard, being the standard the sausage without the addition of essential oil. Results obtained from sensory analysis performed by thirty panelists, who were graduate students, were statistically evaluated through ANOVA and Dunnet tests adopting a confidence level of $95 \%$.

\section{RESULTS AND DISCUSSION}

\section{Chemical composition of oregano essential oil}

The average extraction yield of the oregano essential oil was determined to be $1.33 \mathrm{wt} \% \pm 0.16 \mathrm{wt} \%$, achieved after about $60 \mathrm{~min}$ extraction, which value is similar to that found by von Hertwig (35). Fig. 1 presents the chromatogram of oregano essential oil where one can see that terpinen-4-ol (peak 21, percent area of 21.43), $\gamma$-terpinene (peak 13, percent area of 12.32) and are the major components, followed by carvacrol (peak 30, percent area of 11.67) and thymol (peak 29, percent area of 9.45), a chemical profile very similar to that found by Rodrigues et al. (26).

\section{In vitro antimicrobial activity}

From the disk diffusion method, 9 bacteria were preliminary selected (see Table 1) by taking into account the size of halo formed and their possible occurrence in meat products. This technique is recognized as a useful semi-quantitative method to determine the sensitivity of microorganisms to certain compounds $(16,17,19)$.

As can be seen in Table 1, all bacteria showed to be sensitive to the inhibitory effect of oregano essential oil, except Pseudomonas aeruginosa, which is in agreement with the findings of Sivropoulou et al. (30) in which work three Origanum essential oils (among them Origanum vulgare) did not present antimicrobial activity against this bacterium. The highest antimicrobial activity was observed for Salmonella choleraensius, with the formation of a halo of $29 \mathrm{~mm}$, whereas the lowest activity, $7.2 \mathrm{~mm}$, was verified for Micrococcus luteus (a halo of only $11 \mathrm{~mm}$ ).

In this work, the in vitro antimicrobial activity of oregano essential oil will not be overemphasized as it does not comprise the main contribution of the present work and also because this

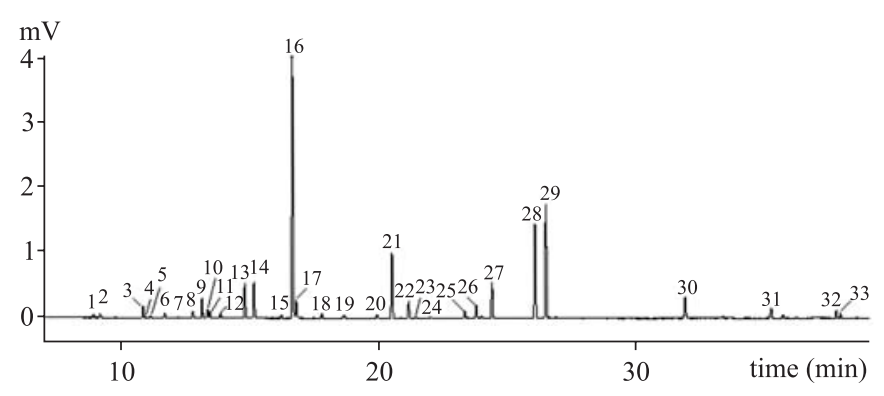

Figure 1. Chromatogram of oregano essential oil obtained by hydrodistillation. Peaks identification: 1 - $\alpha$-thujene $(0.45 \%)$; 2 $\alpha$-pinene (1.88\%); 4- Sabinene (1.50\%); $5 \beta$-pinene (0.19\%); 6Myrcene (1.18\%); 7- $\alpha$-phellandrene $(0.39 \%) ; 8$ - $\alpha$-terpinene (5.58\%); 9-p-cimene (2.99\%); 10- Limonene (2.21\%); 11-1,8cineole (2.31\%); 12 - cis trans- $\beta$-ocimene $(0.81 \%)$; 13 - $\gamma$-terpinene (12.32\%); 14- Trans-sabinene-hydrate $(0.56 \%)$; 15 - Terpinolene (1.97\%); 16-Cis-sabinene-hydrate (3.35\%); 17-Linalool (3.47\%); 18- Trans- $p$-menthenol (1.27\%); 19- Cis- $p$-menthenol (0.89\%); 20- Borneol (0.40\%); 21- terpinen-4-ol (21.43\%); 22- $\alpha$-terpineol (3.17\%); 23- Trans-piperitol (0.37\%); 24- Cis-piperitol (0.40\%); 25- Methyl ether thimol (0.86\%); 26- Methyl ether carvacrol (1.66\%); 27- Linalool acetate (0.36\%); 28- Geraniol/nerol (1.36\%); 29- Thymol (9.45\%); 30- Carvacrol (11.67\%); 31-Geranil/neril acetate $(0.34 \%)$; 32 - $\beta$-caryophyllene (2.24\%); 33- Germacrene $(1.12 \%)$; 34- Spathulenol (0.51\%); 35- Caryophyllene oxide $(0.51 \%)$. 
Table 1. Microorganisms tested for antimicrobial activity through the disk diffusion method.

\begin{tabular}{lcc}
\hline \multicolumn{1}{c}{ Bacterium } & ATCC & $\begin{array}{c}\text { Average halo } \\
(\mathrm{mm})\end{array}$ \\
\hline Gram-positive & & \\
\hline Enterococcus faecalis & 19433 & $16.3 \pm 0.09$ \\
Micrococcus luteus & 10240 & $11.0 \pm 0.09$ \\
Sarcina sp & $*$ & $16.0 \pm 0.09$ \\
Staphylococcus aureus & 6538 & $26.8 \pm 0.08$ \\
Staphylococcus epidermidis & 12228 & $16.8 \pm 0.09$ \\
Streptococcus mutans & 25175 & $16.5 \pm 0.07$ \\
\hline Gram-negative & & \\
\hline Acinetobacter sp & $*$ & $19.0 \pm 0.09$ \\
Aeromonas sp & $*$ & $13.8 \pm 0.08$ \\
Citrobacter freundii & 8090 & $15.8 \pm 0.08$ \\
Escherichia coli & 25922 & $17.3 \pm 0.12$ \\
Klebsiella pneumonae & 13883 & $19.5 \pm 0.09$ \\
Proteus mirabilis & 25933 & $13.3 \pm 0.07$ \\
Proteus vulgaris & 13315 & $17.8 \pm 0.08$ \\
Pseudomonas aeruginosa & 27853 & $\mathrm{~ns} \mathbf{5}^{\dagger}$ \\
Salmonella choleraesius & 10708 & $29.0 \pm 0.08$ \\
Serratia sp & 13880 & $14.3 \pm 0.06$ \\
Shigella flexneri & 12022 & $16.3 \pm 0.06$ \\
Yersinia enterocolitica & 10460 & $17.3 \pm 0.12$ \\
\hline
\end{tabular}

ATCC: American Type Culture Collection - (USA)

*Obtained from Instituto Biológico - Campinas SP; ’not susceptible.

subject has been extensively discussed in the literature by numerous papers (see the review papers of Burt (4); Holley and Patel (15)).

\section{Determination of minimum inhibitory concentration (MIC)}

From Table 2 it can be observed that all microorganisms were susceptible to the action of oregano essential oil, with a variation in the MIC values from 0.23 to $0.69 \mathrm{mg} / \mathrm{mL}$. The generally verified greatest resistance of Gram-negative bacteria to essential oils has been attributed in part to the great complexity of the double membrane-containing cell envelope of these microorganisms in contrast with the single membrane structures of Gram-positive bacteria $(1,13,14,16,17,28,31,34)$. In this work however no significant difference (through statistical Dunnet test at $\mathrm{p}<0.05$ ) was observed between the Gram-positive and Gram-negative bacteria regarding sensitive to the essential oil.

Results of MIC of oregano essential obtained in this work are of the same order of magnitude of those found for thyme essential oil (Thymus vulgaris); e.g., for Escherichia coli, Salmonella sp. and Staphylococcus aureus the respective values found were: $0.5,0.4$ and $0.2 \mathrm{mg} / \mathrm{mL}(13,16,28,34)$, while in
Table 2. Results of minimum inhibitory concentration (MIC) for oregano essential oil.

\begin{tabular}{lcc}
\hline Bacterium & Gram type & $\mathrm{MIC}(\mathrm{mg} / \mathrm{mL})$ \\
\hline Aeromonas $\mathrm{sp}$ & - & 0.460 \\
Enterococcus faecalis & + & 0.460 \\
Escherichia coli & - & 0.460 \\
Klebsiella pneumonae & - & 0.460 \\
Salmonella choleraensius & - & 0.460 \\
Serratia sp & - & 0.598 \\
Shigella flexneri & - & 0.230 \\
Staphylococcus aureus & + & 0.230 \\
Streptococcus mutans & + & 0.690 \\
Average values & - & 0.444 \\
& + & 0.460 \\
\hline
\end{tabular}

this work it was found $0.46 \mathrm{mg} / \mathrm{mL}$ for both Escherichia coli and Salmonella choleraesius and $0.23 \mathrm{mg} / \mathrm{mL}$ for Staphylococcus aureus.

Effect of essential oil concentration on antimicrobial activity against aerobic heterotrofic bacteria in fresh sausage

As mentioned before, to evaluate the antimicrobial activity of oregano essential oil in the food system, it was adopted three distinct oil concentrations with respect to the highest MIC found for all tested bacteria: equal to, 2 times and 5 times of this MIC value. A blank test, without the essential oil was also conducted.

As it can be noticed from Table 3, a significant increase in the number of bacterial cells during the storage period was verified for number 1 sample test (without the oil), especially after the $20^{\text {th }}$ day. For this sample, the initial number of bacterial cells was 3.81 Log CFU/g with the final value as high as 6.78 Log CFU/g. For number 2 batch sample test a progressive increase in the number of bacterial cells was also observed during the storage period but with a final CFU/g value smaller than that found for sample 1 .

For sample $3 \mathrm{CFU} / \mathrm{g}$ values maintained almost constant up to the $30^{\text {th }}$ day with a subsequent significant bacterial growth increase reaching $5.18 \mathrm{Log} \mathrm{CFU} / \mathrm{g}$ at the end of the storage period. For sample 4 a reduction in the number of $\mathrm{CFU}$ was noticed along the storage period, reaching $2.43 \mathrm{Log} \mathrm{CFU} / \mathrm{g}$ after a 35-day storage period.

\section{Effect of essential oil concentration on antimicrobial activity against Escherichia coli inoculated in fresh sausage}

For the samples inoculated with Escherichia coli (concentration of $1 \times 10^{3} \mathrm{MPN} / \mathrm{g}$ ), an increase of bacterial cells was verified to occur in batch sample 1 , which did not have in its formulation the essential oil. As presented in Table 4, this fact becomes clear after 30 days, reaching a final concentration 
Table 3. Time-course of aerobic heterotrofic bacteria growth in fresh sausage containing oregano essential oil in its formulation. Values expressed in terms of $\log \left(\mathrm{CFU} / \mathrm{g}^{*}\right)$.

\begin{tabular}{ccccc}
\hline \multirow{2}{*}{$\begin{array}{c}\text { Time } \\
\text { (days })\end{array}$} & \multicolumn{4}{c}{ Batch sample* } \\
\cline { 2 - 5 } & 1 & \multicolumn{4}{c}{2} & \multicolumn{1}{c}{3} \\
\hline 0 & $3.81^{\mathrm{Ad}}$ & $3.78^{\mathrm{Ac}}$ & $3.94^{\mathrm{Ab}}$ & $3.85^{\mathrm{Aa}}$ \\
10 & $3.99^{\mathrm{Ad}}$ & $3.78^{\mathrm{Bbc}}$ & $3.87^{\mathrm{ABb}}$ & $3.95^{\mathrm{Aa}}$ \\
20 & $4.28^{\mathrm{Ad}}$ & $3.26^{\mathrm{Bc}}$ & $3.30^{\mathrm{Bb}}$ & $3.26^{\mathrm{Bc}}$ \\
25 & $5.28^{\mathrm{Ac}}$ & $4.26^{\mathrm{Bb}}$ & $3.94^{\mathrm{Cb}}$ & $3.68^{\mathrm{Cbc}}$ \\
30 & $5.67^{\mathrm{Ab}}$ & $4.23^{\mathrm{Bb}}$ & $3.90^{\mathrm{BCb}}$ & $3.53^{\mathrm{Cc}}$ \\
35 & $6.78^{\mathrm{Aa}}$ & $5.59^{\mathrm{Aa}}$ & $5.18^{\mathrm{Ba}}$ & $2.43^{\mathrm{Cd}}$ \\
\hline
\end{tabular}

*different letters mean significant difference at $95 \%$ (Dunnet test $\mathrm{p}<0.05$ ), comparison being made between lower case letters in columns with capital letters in rows, with 3 replicate experiments.

${ }^{\dagger} 1$ - without addition of oregano essential oil; 2- essential oil concentration equal to the highest MIC $(0.69 \mathrm{mg} / \mathrm{g})$; 3- essential oil concentration of 2 times of the highest MIC $(1.725 \mathrm{mg} / \mathrm{g})$; 4- essential oil concentration of 5 times of the highest MIC $(3.45 \mathrm{mg} / \mathrm{g})$.

of 5.04 Log MPN/g. For samples treated with the essential oil, it was not detected enhancements in the MPN cells for all concentrations, which allows affirming that the oil acted efficiently.

This inhibitory effect is due probably to the action of the major compound terpinen-4-ol, which is believed to work inhibiting the oxidative inhale, inducing membrane deformation (dilatation) with consequent change in membrane permeability (5). It may be important to mention at this point that there is a lack in the literature concerning the action of oregano essential oil in food systems.

Furthermore, it may be interesting to note that the majority of works published in the literature points out the need of using a high concentration of essential in food systems, typically from 2 to 100 times of the determined in vitro MIC value, depending on the food characteristics (4). In this aspect, results obtained in this work indicate the technical viability of using the oregano essential oil to enlarge the shelf-life of fresh sausage, as a relatively low concentration of oil was sufficient to reduce the number of natural-occurring heterotrofic bacteria as well as E. coli, even inoculated at high concentrations.

\section{Sensory analysis}

Results obtained from the application of the difference control method show the presence of significant differences compared to the standard, with the exception of sample B (half of MIC), which registered the same acceptance of the standard (Table 5). As one could expected based on several studies available in the literature, sensory analysis revealed that acceptance is improved as the oil concentration is reduced.
Table 4. Development of Escherichia coli present in fresh sausage with different oregano essential concentration. Values expressed in terms of $\log (\mathrm{MPN} / \mathrm{mL})$.

\begin{tabular}{crrrr}
\hline \multirow{2}{*}{$\begin{array}{c}\text { Time } \\
\text { (days) }\end{array}$} & \multicolumn{4}{c}{ Batch sample* } \\
\cline { 2 - 5 } & 1 & 2 & 3 & 4 \\
\hline 0 & 4.38 & 3.97 & 4.66 & 4.38 \\
10 & 4.66 & 4.66 & 4.38 & 3.97 \\
20 & 5.04 & 4.66 & 4.66 & 4.38 \\
30 & 5.04 & 4.66 & 4.66 & 4.38 \\
\hline
\end{tabular}

*1- without oregano essential oil but with bacteria inoculum; 2- essential oil concentration equal to the half of highest MIC $(0.345 \mathrm{mg} / \mathrm{g}) ; 3$ essential oil concentration equal to the highest MIC $(0.69 \mathrm{mg} / \mathrm{g})$; $4-$ essential oil concentration 2.5 times of highest MIC $(1.725 \mathrm{mg} / \mathrm{g})$. Average values obtained from 3 replicate experiments.

Table 5. Average grade from sensory analysis of fresh sausage with different oregano essential oil concentrations.

\begin{tabular}{cc}
\hline Sample $^{*}$ & Average grade $^{\dagger}$ \\
\hline A & $5.58^{\mathrm{a}}$ \\
$\mathrm{B}$ & $4.18^{\mathrm{ab}}$ \\
$\mathrm{C}$ & $3.08^{\mathrm{b}}$ \\
$\mathrm{D}$ & $2.58^{\mathrm{bc}}$ \\
$\mathrm{E}$ & $1.98^{\mathrm{c}}$ \\
\hline
\end{tabular}

*A-sample without oregano essential oil; B- essential oil concentration equal to the half of highest MIC $(0.345 \mathrm{mg} / \mathrm{g})$; C- essential oil concentration equal to the highest MIC $(0.69 \mathrm{mg} / \mathrm{g})$; D- essential oil concentration 2 times of highest MIC $(1.725 \mathrm{mg} / \mathrm{g})$; E- essential oil concentration 5 times of highest MIC ( $3.45 \mathrm{mg} / \mathrm{g})$

‘equal letters mean no significant difference at $95 \%$ (Dunnet - $\mathrm{p}<0.05$ )

Thus, the addition of oregano essential oil to fresh sausage shows to be promising because bacteriostatic effect was verified for oil concentrations lower than the highest MIC, which means enhancement in shelf-life. Possibly, reducing the concentration of spices during product formulation will help to achieve a wellbalanced product, satisfying antimicrobial and acceptability consumers' requirements.

\section{CONCLUSIONS}

In this work it was investigated the use of oregano essential oil as antimicrobial agent against several bacteria and also in fresh sausage. Results obtained showed that a good performance is achieved with relatively low concentration of the essential oil, thus leading to extended product shelf-life with the desired slight alteration of the original taste parameters. 


\section{ACKNOWLEDGEMENTS}

The authors thank CNPq, CAPES, SC\&T-RS and FAPERGS for the financial support and scholarships.

\section{RESUMO}

\section{Avaliação da atividade antimicrobiana de óleo essencial de Origanum vulgare em linguiça}

O presente trabalho reporta resultados referentes à testes de atividade antimicrobiana do óleo essencial de orégano (Origanum vulgare) contra várias bactérias em lingüiça. A concentração inibitória mínima (CIM) foi determinada para 9 bactérias aeróbicas heterotróficas. Com base no maior valor encontrado da CIM, testou-se a atividade antimicrobiana para distintas concentrações do óleo essencial in lingüiça fresca. Amostras do sistema alimentar escolhido foram inoculadas com Escherichia coli numa determinada concentração e a evolução temporal do produto concernente ao crescimento microbiano foi monitorada avaliando-se o efeito das diferentes concentrações de óleos essencial aplicadas ao produto inoculado. Os resultados das análises microbiológica e sensorial mostraram que a adição do óleo essencial de orégano a linguiça fresca coloca-se como promissora tendo em vista os efeitos bacteriostáticos observados em baixas concentrações do óleo essencial, inferiores a CIM.

Palavras-chave: Propriedades antimicrobianas, orégano, alimentos, lingüiça

\section{REFERENCES}

1. Bagamboula, C.F.; Uyttendaele, M.; Candan, F.; Daferera, D.; Unli, G.V.; Polissiou, M.; Sokmen, A. (2004). Antimicrobial and antioxidative activities of the essential oils and methanol extracts of S. cryptanha (Montbret et Aucher ex Benth.) and S.multicaulis (Vahl.). Food Chem., 84, 519-525.

2. Baratta, M.T.; Dorman, H.J.D; Deans, S.G.; Figueiredo, C.; Barroso, J.G.; Ruberto, G. (1998). Antimicrobial and antioxidant properties of some commercial essential oils. Flavour and Fragrance J., 13, 235-244

3. Baratta, M.T.; Dorman, H.J.D.; Deans, S.G.; Biondi, D.M.; Ruberto, G. (1998). Chemical composition, antimicrobial and antioxidative activity of laurel, sage, rosemary, oregano and coriander essential oils. J. Essent. Oil Res., 10, 618-627.

4. Burt, S. (2004). Essential oils: their antibacterial properties and potential applications in foods - a review. Int. J. Food Microbiol. 94, 223-253.

5. Cox, S.D.; Mann, J.L.; Bell, H.C.; Gustafson, J.E.; Warmingtn, J.R.; Wyllic, S.G. (2000). The mode of antimicrobial action of the essentia oils of Melaleuca alternifolia (tea tree oil). J. Appl. Microbiol., 88, $170-175$

6. D'Antuono, L.F.; Galleti, G.C.; Bocchini, P. (2000). Variability of essential oil content and composition of Origanum vulgare L. populations from a North Mediterranean area (Liguria Region, Northen Italy). Ann. Bot., 86, 471-478.
7. Daferera, D.J.; Ziogas, B.N.; Polissiou, M.G. (2000). GC-MS analysis of essential oils from some Greek aromatic plants and their fungitoxicity on Penicillium digitatum. J. Agric. Food Chem., 48, 2576-2581.

8. Dapkevicius, A.; Venskutonis, R.; van Beek, T.A.; Linssen, J.P.H (1998). Antioxidant activity of extracts obtained by different isolation procedures from some aromatic herbs grown in Lithuania. J. Sci. Food Agric., 77, 140-146.

9. Deans, S.G.; Svoboda, K.P. (1990). The antimicrobial proprieties of marjoram (Origanum majorana L.) volatile oil. Flavour and Fragrance J., 5, 187-190.

10. Ezzeddine, N.B.; Abdelkefi, M.M.; Ben-Aissa, R.; Chaabouni, M.M. (2001). Antibacterial screening of Origanum majorana L. oil from Tunisia. J. Essent. Oil Res., 13, 295-297.

11. Faria, E.V.; Yotsuyanagi, K. (2002). Técnicas de Análise Sensorial. Campinas: ITAL/LAFISE, p. 116

12. García, M.A.; Sanz, J. (2001). Analysis of Origanum vulgare volatiles by direct termal desorption coupled to gas chromatography-mass spectrometry. J. Chromatogr. A, 918, 189-194.

13. Hammer, K.A.; Carson, C.F.; Riley, T.V. (1999). Antimicrobial activity of essential oils and other plant extracts. J. Appl. Microbiol., 86, 985-990.

14. Helander, I.M.; Alakomi, H.L.; Latva-Kala, K.; Mattila-Sandholm, T.; Pol, I.; Smid, E.J.; Gorris, L.G.M.; Wright, A.V. (1998) Characterization of the action of selected essential oil components on gram-negative bacteria. J. Agric. Food Chem., 46, 3590-3595.

15. Holley, R.A.; Patel, D. (2005). Improvement in shelf-life and safety of perishable foods by plant essential oils and smoke antimicrobials. Food Microbiol., 22, 273-292.

16. Janssen, A.M.; Scheffer, J.J.; Baerheim, S.A. (1987). Antimicrobials activities of essential oils. Pharmaceutics Week lad (Scientific Edition) 9, 193-197.

17. Kalemba, D.; Kunicka, A. (2003). Antibacterial and Antifungal Properties of Essential Oils. Current Medicinal Chem., 10, 813829.

18. Kanazawa, K.; Kawasaki, H.; Samejima, K.; Ashida, H.; Danno, G. (1995). Specific desmutagens (antimutagens) in oregano against a dietary carcinogen, Trp-P-2, are galangin and quercetin. J. Agric. Food Chem., 43, 404-409.

19. Katzung, B.G. (2003). Farmacologia Básica \& Clínica. Guanabara Koogan, $8^{a}$ ed., Rio de Janeiro, RJ.

20. Kim, J.; Marshsll, M.R.; Wei, C. (1995). Antibacterial Activity of Some Essential Oil Components against Five Foodborne Pathogens. J. Agric. Food Chem., 43, 2839-2845.

21. Kokkini, S.; Vokou, D.; Karousou, R. (1991). Morphological and chemical variation of Origanum vulgare L. in Greece. Bot. Chronica, 10, 337-346.

22. Kokkini, S.; Karousu, R.; Dardioti, A.; Krigas, N.; Lanaras, T. (1997) Autumn essential oils of Greek oregano Phytochemistry, 44, 883886.

23. Lis-Balchin, M.; Buchbauer, G.; Hirtenlehner, T. (1998). Antimicrobial activity of Pelargonium essential oil added to a quiche filling as a model food system. Letters of Appl. Microbiol., 27, 207210 .

24. Reverchon, E. (1997). Supercritical fluid extraction and fractionation of essential oils and related products. J. Supercrit. Fluids, 10, 1-37.

25. Rodrigues, M.R.; Caramão, E.B.; Santos, J.G.; Dariva, C.; Oliveira, J.V. (2003). The effects of temperature and pressure on the characteristics of the extracts from high-pressure $\mathrm{CO}_{2}$ extraction of Majorana hortensis Moench. J. Agric. Food Chem., 51, 453456.

26. Rodrigues, M.R.; Krause, L.C.; Caramão, E.B.; Santos, J.G.; Dariva, C.; Oliveira, J.V. (2004). Chemical composition and extraction yield of the extract of Origanum vulgare obtained from sub and supercritical $\mathrm{CO}_{2}$. J. Agric. Food Chem., 52, 3042-3047. 
27. Russo, M.; Galleti, G.C.; Bocchini, P.; Carnacini, A. (1998). Essential oil composition of wild populations of Italian Oregano species (Origanum vulgare sp. Hirtum (Link) Iestswaart): A priliminary evaluation of their use in chemotaxonomy by cluster analysis. 1 . Inflorescences. J. Sci. Food Agric., 46, 3741-3746.

28. Shapiro, S.; Meier, A.; Guggenheim, B. (1994). The antimicrobial activity of essential oils and essential oil components towards oral bacteria. Oral Microbiol. Immunology, 9, 202-208.

29. Silva, N.; Junqueira, V.C.A.; Silveira, N.F.A. (1997). Manual de métodos de análise microbiológica de alimentos. Livraria Varela, São Paulo.

30. Sivropoulou, A.; Papanikolaou, E.; Nikolaou, C.; Kokkini, S.; Lanaras, T.; Arsenakis, M. (1996). Antimicrobial and citotoxic activities of origanum essential oils. J. Agric. Food Chem., 44, 1202-1205.

31. Tepe, B.; Donney, E.; Unlu, M.; Candan, F.; Daferera, D.; Unlu, G.V.; Polissiou, M.; Sokmen, A. (2004). Antimicrobial and antioxidative activities of the essential oils and methanol extracts of $S$. cryptanha (Montbret et Aucher ex Benth.) S. multicaulis (Vahl.). Food Chem., 84, 519-525.

32. Vági, E.; Simándi, B.; Suhajda, Á.; Héthelyi, É. (2005). Essential oil composition and antimicrobial activity of Origanum majorana L. extracts obtained with ethyl alcohol and supercritical carbon dioxide. Food Res. Int., 38, 51-57.

33. Vokou, D.; Kokkini, S.; Bessiere, J-M. (1993). Geographic variation of Greek Oregano (Origanum vulgare ssp. hirtum) essential oils. Biochem. Syst. Ecol., 21, 287-295.

34. Velickovic, D.T.; Randjelovic, N.V.; Ristic, M.S.; Smelcerovic, A.A.; Velickovic, A.S. (2002). Chemical composition and antimicrobial action of the ethanol extracts of S. pratensis L. S. glutinosa L. S. aethiopis L. J. Serbia Chem. Soc., 67, 639-646.

35. von Hertwig, I.F. (1986). Plantas aromáticas e Medicinais Origanum vulgare L.; Icone Editora Ltda: São Paulo, SP. p. 361. 